\title{
Effectiveness of Lavender Aromatherapy and Natural Sound Music Against Anxiety Level in VIA Examination Patients
}

\author{
$1^{\text {st }} \mathrm{S}$ Mujahidah \\ Department of Midwifery \\ STIKES Karya Husada Semarang \\ Semarang, Indonesia \\ saadah.mujahidah16@gmail.com
}

\author{
$2^{\text {nd }}$ Fery Agusman Motuho Mendrofa \\ Department of Nursing \\ STIKES Karya Husada Semarang \\ Semarang, Indonesia
}

\begin{abstract}
Visual inspection acetic acid (VIA) is a screening to detect the presence of cervical pre-cancerous lesions so that often causes anxiety in patients who are often ignored by health workers. The diagnosis of cancer often caused anxiety and depression for a patient so lose the spirit for life. Early detection of anxiety disorders is very important because anxiety can be complicated the medical condition. This paper proposes lavender aromatherapy and natural sound music to overcome the anxiety of VIA examination patients. Aromatherapy and natural sound music can influence levels of stress hormones in the body and affect brain waves which can cause feelings of relaxation for patients. The design of this study was quasi-experimental using pre and posttest with a control group design, there were 64 categorized into an intervention group $(n=16)$ used aromatherapy, $(n=16)$ used natural sound music, $(n=16)$ used a combination of aromatherapy and natural sound music and control groups $(n=16)$. The intervention was carried out for 15 minutes where respondents waited for the VIA examination. The Kruskal-Wallis test showed a $P$ value of $0,000(<0.05)$, which indicated that there was a statistically significant effect of the lavender aromatherapy and nature sound music on the anxiety level in the VIA examination patients.
\end{abstract}

Keywords-Lavender Aromatherapy, Natural Sound Music, VIA Examination Patients

\section{INTRODUCTION}

Cancer is the second caused of death in the world. Based on WHO data, there were 9.6 million deaths in 2018 caused by cancer. Globally 1 from 6 death is caused by cancer [1]. The second most common cancer in women is cervical cancer. It is estimated that there are 570,000 new cases of cervical cancer in 2018 ( $84 \%$ of new cases worldwide). WHO reports that are around 311,000 women died of cervical cancer in 2018 , more than $85 \%$ of this death is in low and middle-income countries [2]. Early detection can prevent death caused by cancer. There are two components in early detection, screening, and early diagnosis. The results of screening can be used as reference material to establish an early diagnosis. One of the screening programs is VIA (visual inspection with acetic acid). The VIA test is a visual test using a vinegar acid solution ( $2 \%$ acetic acid) and the iodine lugol solution on the cervix to see the changed color that occurs after smearing. The aim is to see the presence of dysplasia cells as one of the early detection methods for cervical cancer
[3]. VIA examination is a screening to detected cervical precancerous lesions so that often caused anxiety in patients. A study in Singapore found that there were $12.77 \%$ of patients suffering from anxiety, but the anxiety was often ignored by health workers. Most health workers only attention how to treat cancer patients without seeing the anxiety of patients [4]. The cancer diagnosis is often resulted in anxiety and depression in the patient and caused loses of hope for life [5,6]. In general female patients had higher anxiety levels compared to male patients [7]. Anxiety is a common psychiatric condition in patients and is often undiagnosed and not treated adequately. Mental disorders such as anxiety can be accompanied by physical symptoms, and the patient comes to primary care services with physical complaints more often than psychiatric complaints. However, due to various factors, physical symptoms experienced patients with psychiatric conditions are often not well diagnosed [8]. Patients with mental disorders first come to primary care generally with somatic complaints, this complaint is often associated with depression and anxiety [9]. The cause of anxiety disorders until now cant be ascertained. However, various factors influence the occurrence of anxiety disorders in a person. These factors include medical illness, demographic factors, psychosocial stress, and so on [10]. The results showed that anxiety disorders, especially phobias, were associated with ischemic heart disease and anxiety relationships with migraines. Early detection of anxiety disorders is very important to give more quick treatment to the patient and prevent severe mental disorders. Diagnosis and treatment of anxiety are important because anxiety can complicate the treatment of a medical condition [11]. Anxiety also caused a decrease in efforts to search the health assistance and decrease compliance with took medication when somatic disorders appeared [12].

This research proposes giving aromatherapy and music to reduce the level of anxiety experienced by patients. The provision of non-pharmacological therapies such as relaxation is better in reducing anxiety compared to pharmacological therapy [6]. Music can affect stress hormones in the body and affect body systems. Natural sound music is music that has a slow tempo with a low tone and without lyrics is a non-pharmacological therapy that can make relaxation in patients [13]. Besides giving 
aromatherapy also proven effective for reducing anxiety in patients [14-17].

\section{METHOD}

This research is quasi-experimental (pre and posttest with control group design). Performed at the Community Health Center (Puskesmas). The sampling technique used was simple random sampling by close envelope involving 64 respondents. Respondents were categorized into four groups, namely intervention ( $\mathrm{n}=16)$ given aromatherapy lavender, $(\mathrm{n}=16)$ given natural sound therapy, $(\mathrm{n}=16)$ given a combination of aromatherapy and natural sound music and control groups $(n=16)$. The intervention was carried out for 15 minutes where the respondent waited for time to do an IVA examination that was given a pree and post-test using the DASS 21 questionnaire. The research flowchart is shown in figure 1 .

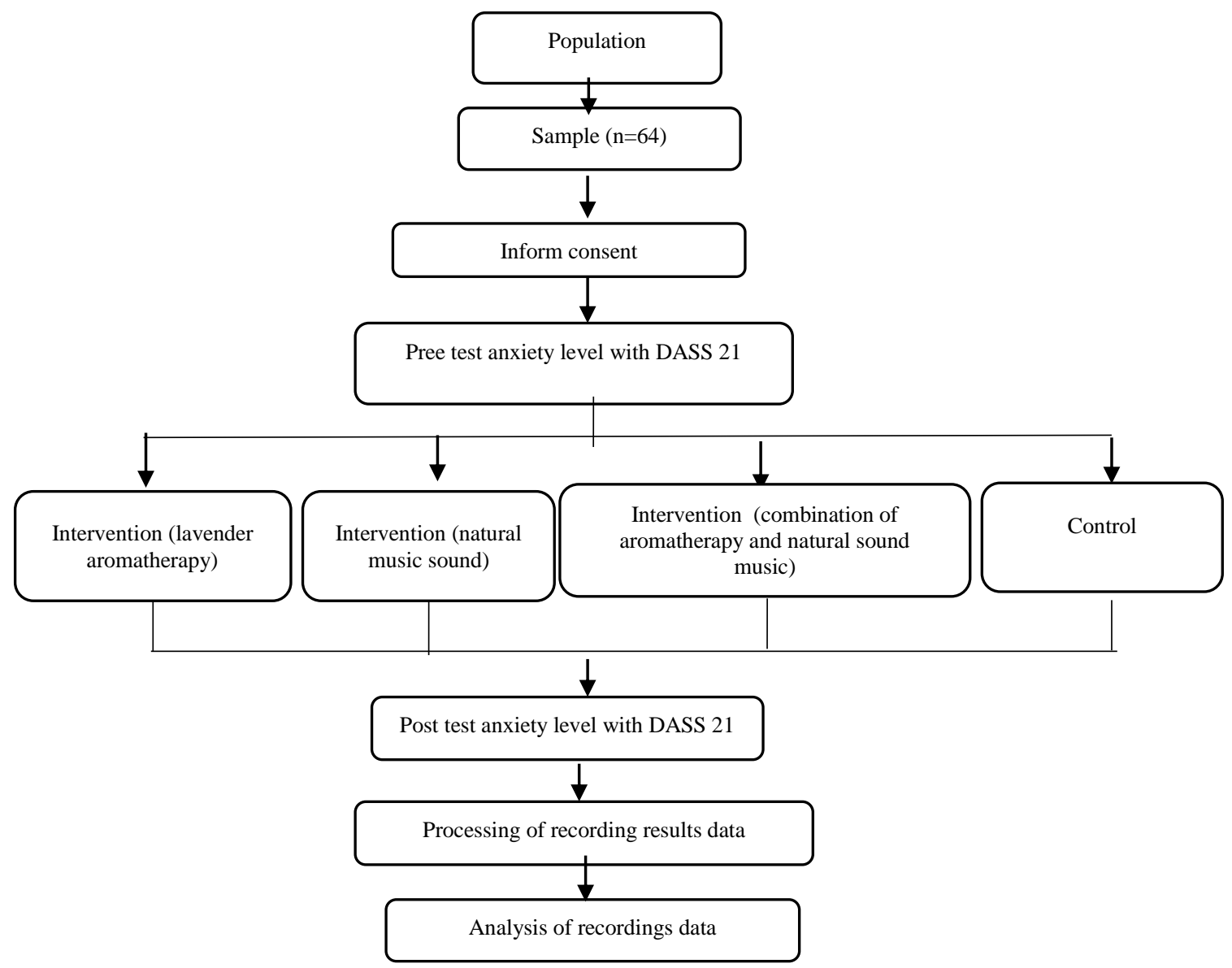

Figure 1. Flowchart

\section{RESULT AND DISCUSSION}

Respondents were patients who will get a VIA examination. While the data collected comes from the identity data and the results of respondents' answers on the DASS 21 questionnaire sheet. The informed consent was immediately made to the respondents by explaining the procedures and benefits of the study.

\section{A. Characteristics of Respondent}

This study shows that the majority of respondents have age 20-35 years (54.7\%), education in bachelor (43.8\%), and have paritas multipara (57.8\%). As presented in Table 1 .

TABLE 1. CHARACTERISTICS OF RESPONDENTS

\begin{tabular}{|c|l|l|}
\hline $\begin{array}{l}\text { Characteristics of } \\
\text { Respondent }\end{array}$ & Frequency & $\begin{array}{l}\text { Percent } \\
(\%)\end{array}$ \\
\hline Age & & \\
\hline Age 20-35 & 35 & 54.7 \\
\hline Age $>35$ & 29 & 45.3 \\
\hline
\end{tabular}

\begin{tabular}{|c|l|l|}
\hline Education & & \\
\hline Junior High & 2 & 3.1 \\
\hline Senior High & 17 & 26.6 \\
\hline Diploma & 9 & 14.1 \\
\hline Bachelor & 28 & 43.8 \\
\hline Post Graduated & 8 & 12.5 \\
\hline Parity & & \\
\hline Primipara & 24 & 37.5 \\
\hline Multipara & 37 & 57.8 \\
\hline Grandemultipara & 3 & 4.7 \\
\hline
\end{tabular}

\section{B. Statistical Analysis}

Table 2 shows that there was a mean decrease in anxiety levels in the intervention with aromatherapy group by 5.06 , the natural sound music group decreased by 4.18 , the combination group with aromatherapy and natural sound music by 6.062 and there was a decrease anxiety level of 0.81 in the control group. 
TABLE 2. DIFFERENCE BETWEEN ANXIETY LEVELS BEFORE AND AFTER TREATMENT

\begin{tabular}{|c|c|c|c|c|c|c|}
\hline \multirow[t]{2}{*}{ Variable } & \multirow[t]{2}{*}{ Group } & \multirow{2}{*}{$\begin{array}{c}\text { Pre Test } \\
\text { Mean } \pm \text { SD }\end{array}$} & \multirow{2}{*}{$\begin{array}{c}\text { Post Test } \\
\text { Mean } \pm \text { SD } \\
\end{array}$} & \multicolumn{2}{|c|}{ Mean rank } & \multirow[t]{2}{*}{$p$-value } \\
\hline & & & & Negative & Positive & \\
\hline \multirow{4}{*}{ Anxiety Level } & Aromatherapy. & $9.000 \pm 3.425$ & $3.937 \pm 1.062$ & 7.50 & 0 & 0.001 \\
\hline & Natural sound music & $9.875 \pm 3.403$ & $5.687 \pm 1.990$ & 8.00 & 0 & 0.001 \\
\hline & $\begin{array}{l}\text { Combination } \\
\text { aromatherapy and } \\
\text { natural sound music. }\end{array}$ & $10.937 \pm 4.250$ & $4.875 \pm 2.305$ & 8.50 & 0 & 0.000 \\
\hline & Control & $8.375 \pm 4.209$ & $7.562 \pm 2.308$ & 8.69 & 7.21 & 0.583 \\
\hline
\end{tabular}

In the test before and after the treatment group, p-value of aromatherapy (0.001), natural sound (0.001) and combination aromatherapy and natural sound (0.000) $<0.05$ can be concluded in the aromatherapy intervention group, natural sound music, and combination aromatherapy and natural sound music there is a statistically significant difference in the level of anxiety before and after treatment. In the control group obtained values of $0.583>0.05$, it can be concluded there were no significant differences in the level of anxiety before and after treatment in the control group.

\begin{tabular}{lccc}
\multicolumn{4}{c}{ TABLE 3. KRUSKALL-WALLIS TEST } \\
\hline Group & $\mathrm{n}$ & $\begin{array}{l}\text { Mean } \\
\text { Rank }\end{array}$ & p-value \\
& 16 & 20.84 & \\
\hline Aromatherapy. & 16 & 34.66 & \\
Natural sound music & 16 & 26.59 & 0.000 \\
$\begin{array}{l}\text { Combination aromatherapy and } \\
\text { natural sound music. }\end{array}$ & 16 & 47.91 & \\
Control & & \\
\hline
\end{tabular}

The Kruskal-Wallis test demonstrated a significant difference in the rate of anxiety level between aromatherapy, natural sound music, combination and control groups $(p-0.00)$. That means aromatherapy and natural sound music can reduce the anxiety level for a patient with VIA examination.

Anxiety is an individual's response to protection or stressors that will come both from within the individual and from the environment [18]. This emotional response arises from caused that are not specific so that individuals feel uncomfortable and threatened [19]. Anxiety can be a normal or pathological response, this depends on the intensity and duration of the anxiety and coping abilities of the individual [20]. In everyday life, normal anxiety is needed to achieve certain satisfaction and enjoyment at work (performance) but excessive anxiety will interfere with performance and needs to be addressed. This excessive anxiety can be in the form of anxiety that is not tied to the form of ideas, things, or certain conditions caused by various aspects of life such as in a total anxiety disorder, or in the form of anxiety related to certain conditions or situations such as phobic anxiety, social phobia, disorder obsessive-compulsive disorder, and other anxiety [18].

The essential oil used in this study is lavender, which is used to reduce anxiety. Aroma utilizes the olfactory function as a medium for stimulating the aroma of odor that can stimulate the limbic system in the hypothalamus so that it triggers alpha waves to provide a relaxing effect that is expected to affect reducing anxiety levels [16]. The main substances contained in lavender are linalool and linalyl acetate which are substances that can provide a relaxing effect when anxious and panic. The effect of aromatherapy will only affect the patient's physiological condition [15].

The purpose of giving music therapy is to help patients express feelings, reduce muscle tension and reduce anxiety which will biologically increase muscle energy, causing the frequency of breathing and pulse to be regular and stable blood pressure $[11,21,22]$. Music can be useful for someone to be more relaxed, cause a sense of security, prosperity, relief of pain and reduce the level of anxiety of patients who will undergo a medical procedure $[21,23,24]$. Nature sounds music is not part of classical music. This type of music is a discovery due to the modernization of sound recording technology. Nature sounds music is an integrative form of classical music with natural sounds. This musical composition is accompanied by the background sound of ocean waves or the rustling of trees and other natural sounds. This type of nature sound tends to bring the listener closer to the natural atmosphere. For children, the sound of this nature not only arouses certain associations but also is a certain stimulus as a learning tool. This musical accompaniment in a calm situation while studying is very helpful in strengthening his imagination and association [13,25-27].

\section{CONCLUSION}

This study showed that aromatherapy and natural sound music can reduce the anxiety level for a patient with a VIA examination. The result of this study can be useful in the planning of VIA examination programs so the patients can feel relaxed and comfortable for VIA examination.

\section{REFERENCES}

[1] World Health Organization. Cancer 2018 [Available from: https://www.who.int/news-room/fact-sheets/detail/cancer.

[2] World Health Organization. Human Papillomavirus (HPV) and Cervical Cancer 2019 [Available from: https://www.who.int/news-room/fact-sheets/detail/humanpapillomavirus-(hpv)-and-cervical-cancer.

[3] Rasjidi I. Epidemiologi kanker serviks. Indonesian Journal of cancer. 2009;3(3).

[4] Beck KR, Tan SM, Lum SS, Lim LE, Krishna LK. Validation of the emotion thermometers and hospital anxiety and depression scales in $S$ ingapore: Screening cancer patients for distress, anxiety and depression. Asia-Pacific Journal of Clinical Oncology. 2016;12(2):e241-e9. 
[5] Bener A, Alsulaiman R, Doodson L, El Ayoubi H. Comparison of Reliability and Validity of the Breast Cancer depression anxiety stress scales (DASS-21) with the Beck Depression Inventory(BDI-II) and Hospital Anxiety and Depression Scale (HADS). Int J Behav Res Psychol. 2016;4(4):197-203.

[6] Butow P, Price MA, Shaw JM, Turner J, Clayton JM, Grimison $\mathrm{P}$, et al. Clinical pathway for the screening, assessment and management of anxiety and depression in adult cancer patients: Australian guidelines. Psycho-Oncology. 2015;24(9):987-1001.

[7] McMullen M, Lau PK, Taylor S, McTigue J, Cook A, Bamblett M, et al. Factors associated with psychological distress amongst outpatient chemotherapy patients: An analysis of depression, anxiety and stress using the DASS-21. Applied Nursing Research. 2018;40:45-50.

[8] Sitorus PE, Fitrikasari A. Gambaran Tingkat Kecemasan Dan Hubungannya Dengan Berbagai Faktor Pada Pasien Rawat Jalan Puskesmas (Studi Deskriptif Analitik Di Puskesmas Halmahera Semarang): Diponegoro University; 2016.

[9] Elena Garralda M. The interface between physical and mental health problems and medical help seeking in children and adolescents: a research perspective. Child and Adolescent Mental Health. 2004;9(4):146-55.

[10] Merikangas KR, Pine D. Genetic and other vulnerability factors for anxiety and stress disorders. Neuropsychopharmacology: The fifth generation of progress. 2002:867-82.

[11] Parlar Kilic S, Karadag G, Oyucu S, Kale O, Zengin S, Ozdemir $\mathrm{E}$, et al. Effect of music on pain, anxiety, and patient satisfaction in patients who present to the emergency department in Turkey. Japan Journal of Nursing Science. 2015;12(1):44-53.

[12] Smith IG, Parker G, Cvejic E, Vollmer-Conna U. Acute coronary syndrome-associated depression: the salience of a sickness response analogy? Brain, behavior, and immunity. 2015;49:1824

[13] Laska Y, Suryono S, Widyawati MN, Suwondo A, Kusworowulan S. Effect Of Nature Sound Therapy On The Level Of Cortisol In Postpartum Primipara. Belitung Nursing Journal. 2018;4(1):26-30.

[14] Agustie PR, Hadisaputro S, Runjati R, Soejoenoes A, Mashudi ID, Widyawati MN. Effect of Oxytocin Massage Using Lavender Essential Oil on Prolactin Level and Breast Milk Production in Primiparous Mothers After Caesarean Delivery. Belitung Nursing Journal. 2017;3(4):337-44.

[15] Dewi A, Prima I. Lavender Aromateraphy as a Relaxant. E-Jurnal Medika Udayana.2(1):21-53.

[16] Pitman V. Aromatherapy: a practical approach: Nelson Thornes; 2004.
[17] Widyawati MN, Hadisaputro S, Anies A, Soejoenoes A. Effect of Massage and Aromatherapy on Stress and Prolactin Level among Primiparous Puerperal Mothers In Semarang, Central Java, Indonesia. Belitung Nursing Journal. 2016;2(4):48-57.

[18] Maramis A, Dharmono S, Maramis M. Penanganan Depresi dan Anxietas di pelayanan Primer. Indopsy, Surabaya. 2003.

[19] Sadock BJ, Sadock VA. Kaplan and Sadock's synopsis of psychiatry: Behavioral sciences/clinical psychiatry: Lippincott Williams \& Wilkins; 2011.

[20] Widianti E. Pengaruh terapi logo dan terapi suportif kelompok terhadap ansietas remaja di rumah tahanan dan lembaga pemasyarakatan wilayah provinsi Jawa Barat. Jakarta: Fakultas Ilmu Keperawatan Universitas Indonesia. 2011.

[21] Aung SK, Lee MH. Music, sounds, medicine, and meditation: An integrative approach to the healing arts. Alternative \& Complementary Therapies. 2004;10(5):266-70.

[22] Thoma MV, Zemp M, Kreienbühl L, Hofer D, Schmidlin PR, Attin T, et al. Effects of music listening on pre-treatment anxiety and stress levels in a dental hygiene recall population. International journal of behavioral medicine. 2015;22(4):498505.

[23] Leardi S, Pietroletti R, Angeloni G, Necozione S, Ranalletta G, Del Gusto B. Randomized clinical trial examining the effect of music therapy in stress response to day surgery. British journal of surgery: Incorporating european journal of surgery and swiss surgery. 2007;94(8):943-7.

[24] Petrovsky D, Cacchione PZ, George M. Review of the effect of music interventions on symptoms of anxiety and depression in older adults with mild dementia. International Psychogeriatrics. 2015;27(10):1661-70.

[25] Arai YC, Sakakibara S, Ito A, Ohshima K, Sakakibara T, Nishi T, et al. Intra-operative natural sound decreases salivary amylase activity of patients undergoing inguinal hernia repair under epidural anesthesia. Acta Anaesthesiologica Scandinavica. 2008;52(7):987-90.

[26] Lee OKA, Chung YFL, Chan MF, Chan WM. Music and its effect on the physiological responses and anxiety levels of patients receiving mechanical ventilation: a pilot study. Journal of clinical nursing. 2005;14(5):609-20.

[27] Tsuchiya M, Asada A, Ryo K, Noda K, Hashino T, Sato Y, et al. Relaxing intraoperative natural sound blunts haemodynamic change at the emergence from propofol general anaesthesia and increases the acceptability of anaesthesia to the patient. Acta anaesthesiologica scandinavica. 2003;47(8):939-43. 